\title{
Early Iraqi Arab Nationalism against the Turkish Nationalism and the Westernization (1905-1918)
}

\author{
Rekurd S. Maghdid \\ Economy and Administration Department, Faculty of Humanities and Social Sciences, Koya University \\ University Park, Danielle Mitterrand Boulevard, Koysinjaq KOY45, Iraq
}

\begin{abstract}
In the Nineteenth century, nationalism spread the Arab countries. This paper is going to argue the existence of Arab nationalism, focusing on Iraq. It is going to discuss the reasons why Arabs in Iraq, including the deputies of Baghdad, Basra and Mosul, supported the Ottoman Sultan and to some extent they opposed the Turkish members of CUP. Moreover, this work concentrates on the policies of the late Ottoman government toward the Arabs. Many researchers argue that the Iraqi Arab Nationalists were proOttomans or at least the Iraqi Arabs were welcomed the Young Turks reforms. Some other researchers took some tribal leaders (Sheikh)s as examples of friendship of Arabs with Young Turks or Arabs with British administration. Nonetheless, one of the most important thing that $l$ would like to point out in my argument is the Iraqi opposition towards the European occupation and existence in the region. The alliance that the British Army made with the coming Iraqi King, Feisal bin Sharif bin Ali, cannot be regarded as a part of the Arab nationalism in Iraq, since Feisal was not Iraqi and posed by force to the Iraqis. The paper discusses how Iraqi Arab Nationalists opposed the Western companies during the Ottomans in 1909 and 1913. The Arab Nationalists have also revolted against the British occupation in Iraq in 1915. Therefore, this research is to the fact that Arab nationalism is a kind of Sultanism, antiEuropeanism, Islamism and anti-Young Turks. To prove these historical misunderstand, many old and new (Arabic, Turkish and English) resources were used.
\end{abstract}

Keywords: Arab nationalism, Iraq, Ottomans, Britain, Young Turks, King Faisal,CUP, Islamism, Europeanism, Westernization

\section{Introduction}

Due to the importance of nationalism, there are several definitions of Nationalism. Nonetheless, nationalism is mainly related to linguistic, cultural, religious, and historical heritages of an ethnic people. Ernest Gellner, in his book "Nations and Nationalism", claims that nationalism involves the identification of an ethnic identity with a state [Ernest Gellner. Nations and nationalism, Bölüm 1-2; Bölüm 4-9. Wiley-Blackwell. 2006. p. xxxvi]. In addition, some other writers liken nationalism to a cultural, intellectual or military movement. For instance, Thomas Blank and Peter Schmidt argue that "It is also used to describe a movement to establish or protect a homeland (usually an autonomous state) for an ethnic group. In some cases the identification of a homogeneous national culture is combined with a negative view of other races or cultures." [Thomas Blank and Peter Schmidt, National Identity in a United Germany: Nationalism or Patriotism? An Empirical Test with Representative Data, in Political Psychology, Vol. 24, No. 2. 2003]

The main aims of nationalisms are to have a collective identity, that is a nation or a group of people must be autonomous, united, and have one single national culture [Hutchinson, John and Smith, Anthony D. Nationalism. Oxford Readers. Oxford University Press: Oxford. 1994. pp. 4-5]. All the nationalists are in harmony in the fact that a nation should be united in terms of their ideology and purposes. A nation should be independent and should have a common interest in the foreign affairs. Nonetheless, a large number of nationalists argue that individuals have an important role in their own national identity [Smith D. Anthony. Nationalism: theory, ideology, history. WileyBlackwell. 2001. pp 17-8]. In other words, individual interests can be kept safe within the general or common interests of the whole nation but the priority should be given to the national interests. Therefore, nationalism can be encountered along the existence of the individualism.

Since nationalism is so wide that gathered as well as differed many peoples and intellectuals, it can be demonstrated in different ways. Sometimes, nationalism is reactionary that tries to turn back to a national past. This kind calls for the expulsion of foreigners. It stems out as a reaction to the pressures that aimed at reducing the power and existence of that nation or sometimes genocide. Furthermore, nationalism, some other times, is revolutionary. Revolutionary nationalisms aim at the establishment of an independent state so as to be a homeland to a specific or two ethnic groups of peoples [Joseph Scott. The Black revolts: racial stratification in the U.S.A. : the politics of estate, caste, and class in the American society. Transaction Publishers. 1976. pp. 158-9]. This type of nationalism often stems out from deep emotions and it is aggressive [I bid]. Therefore, the aims of nationalisms are different and those aims decide the type of each nationalism.

The history of nationalism goes back to the late eighteenth century. Nevertheless, a part of historians relate the term nationalism to the late-18th century American Revolution and French Revolution. On the other hand, some other historians refer back solely to the ultra-nationalist party in France during the French Revolution [Eric Hobsbawm, The Age of Revolution, 1789-1848, New York: New American Library, 1962, p. 112]. By then, the term nationalism became widespread and known as the most significant political and social forces in the history. Due to the influences of nationalism the world map have changed for many times, that is, some nations became more powerful and could score triumphs while some other nations were defeated. 


\section{International Journal of Science and Research (IJSR) \\ ISSN (Online): 2319-7064 \\ Index Copernicus Value (2013): 6.14 | Impact Factor (2014): 5.611}

The triumphs of the French revolution, indeed, are absolutely related to the impact of the nationalism. These successes were soon noticed by all the nations in the Europe. In that period, the Ottoman Empire was faced to many nationalist oppositions in the West and the Balkans. These defeats were criticized by the intellectual Turks and let nationalism to be a solution for the defeats. Arabs, in addition, reacted to the developments in the region and took advantages of the Ottoman loss of power. Therefore, The Arab nationalism is traced back to the late $19^{\text {th }}$ century and the early $20^{\text {th }}$ century in which it can be related the Young Turks' movement as well as the existence of the Western powers in the Middle East.

This research deals with Arab nationalism in Iraq before the establishment of the Kingdom of Iraq. The paper argues the existence of Arab nationalism, focusing on Iraq. In the introduction, different definitions on nationalism are mentioned as well as the types and history of nationalism in the world. In the second chapter, the paper explains how Arab nationalism appeared along with the factors that had influences on the emergence of the Arab nationalism during the Ottoman rule. Furthermore, in the third chapter, the argument is whether it is Iraqi Arab nationalism or AntiWesternism during the Ottomans. It exemplifies two cases during the Ottomans that Iraqi Arabs totally opposed the Westernism. Meanwhile, Iraqi Arabs' revolts against the United Kingdom are explained in the fourth chapter as a course Arab anti-Westernism. Finally, the paper ends with a concluding chapter.

\section{Early Arab nationalism}

In the nineteenth and early twentieth century, the Ottoman Empire suffered from several aggressive battles and oppositions from the non-Turk nations. In most of the battles and wars the Ottoman Empire scored defeats until it led to the disestablishment of the empire. By contrast, in the late $19^{\text {th }}$ century the Western Europe entered a new era of technological as well as military triumphs. These successes were attributed to the emergence of nationalism and patriotism by the Ottoman peoples and empire [Ernest Dawn. "The Origions of Arab Nationalism" in Rashid Khalidi, et al. (eds), The Origins of Arab Nationalism. (New York, 1991), p. 6]. Such triumphs were also related to the sense of nostalgia for their states [I bid]. Meanwhile, it was claimed that the Ottoman defeats stem out from Islamic priority over nationalism and thus a sound of nationalism was raised parallel to religious ideology. By then, an attention for loyalty to the Fatherland can be noticed among intellectuals.

Muslim and non-Muslim intellectuals inside the Ottoman Empire started to form small as well as large groups raising the notion of the nationalism. It is untrue to say that only non-Turkish intellectuals thought of nationalism because the Turkish nationalism started before almost all the peoples ruled by the Ottomans. After the defeats that the Ottoman Empire suffered from in the late $18^{\text {th }}$ century, some of the Turkish intellectuals started to think of the successes of the Western Europe. These Turkish intellectuals, Young Turk, tried to reform in the administration of the Ottoman Empire and opposed the monarchy of the Ottoman Sultan [John L.
Esposito. The Oxford dictionary of Islam. Oxford University Press: US. 2004. p. 344]. Furthermore, this Young Turk group became a sample of nationalism that encouraged other nations like Arabs to follow the same path to stop further declines of Islam in political equations [I bid].

The Arab Nationalism was first occurred in the Arab literature. Arab poets tried to unite the regional Arab nationalisms in Levant and Egypt in the mid-nineteenth century. The main reason behind that was to unite Muslim and non-Muslim Arabs to challenge Ottomanism. This can be seen in the poems written by Arab nationalism at that time. For instance, Ibrahim al-Yazigi, a Syrian Christian philosopher, called for the Arabs to unite and revolt the Turks [Samir Kassir. Being Arab. Verso. 2006. p. 45]. AlYazigi claimed that the "national identity" is the best solution to recover to the past triumphs. Furthermore, in one of his poems, Al-Yazigi stated

"Awaken, O Arabs and leave slumber aside As danger's flood washes your knees in its tide"

Although Arab poets had a sense of loyalty to the lost ancient vitality, the patriotism that the Arab intellectuals concentrated on can not be regarded as the nostalgia for the Arab Fatherland. There is a significant clue focusing on some of Arab nationalists' loyalty of the Fatherland of the Ottoman Empire not just the Arab Fatherland in which the same sense can be noticed within other nations. Take Turks as an evidence for this fact, the losses that the Ottomans encountered in the Balkans and the Northern Africa pulled the Turkish intellectuals to have a feeling of loyalty for the Ottoman Fatherland. Nevertheless, a difference was occurred between the Arab and Turkish nationalisms. Unlike Turks, some of Arab intellectuals, within their feelings towards nationalism, criticized Ottoman Turks in their newspapers and magazines at that time [Halim Barakat. The Arab world: society, culture, and state. University of California Press. 1993. pp. 239-40].

The Arab intellectuals were, generally, educated either in Europe or in Istanbul. Those intellectuals were not different from the Young Turks in their intentions for reform. Nonetheless, they did not want to demonstrate against the monarchy of the Sultan. Some of the Arab intellectuals were extremely nationalists. Those Arab nationalists were, to some extend, specific and were from Egypt and Levant (Bilad a-Sham). The Arab intellectual nationalist circles stemmed out from two factors. Firstly, the existence of some Western Christian missionaries establishing secret societies inside the Ottoman Empire [Hiro, Dilip. "Arab nationalism." Dictionary of the Middle East. St. Martin's Press. 1996. p 24]. Secondly, most of the Arab nationalist intellectuals lived in Europe and encountered the developments as well as the successes of the West in that era.

It is taken for granted that a kind of unity can be noticed inside Arabs towards nationalism until the very beginning of twentieth century. The Western Christian missionaries tried to split Arabs from the Ottoman Empire so as to weaken both of Islam and its caliphate. First, they began in Egypt then in Beirut, or the whole Levant. In the newspaper that are funded, or in any ways, financially supported by the 


\section{International Journal of Science and Research (IJSR) \\ ISSN (Online): 2319-7064 \\ Index Copernicus Value (2013): 6.14 | Impact Factor (2014): 5.611}

West, the Christian social groups attacked Ottoman Turks and many times condemned them for betraying Islam. Therefore, it is obvious that the newspapers of that period were filled with the criticisms against the Ottoman policies.

The Arab Intellectuals criticized Ottomans for having contracts with European companies and the British-Ottoman relations while, Turkish intellectuals supported the openness of the Empire towards the West [Fatma Müge Göçek. Social constructions of nationalism in the Middle East. SUNY Press. 2002. p. 33]. That is, the Young Turks tried to modernize the Ottoman Empire though applying Western systems of ruling. The Arabs, by contrast, were not so familiar with the Western system and thought that these are new methods of Turkification. By this, the Christian missionaries tried to create a sense claiming that Arabs are worthier to rule the entire Islamic world including the Ottomans than Turks. Thus, they tried to split Turks and Arabs. Therefore, Arab nationalism, at that period, was mainly related to the concepts of Islam.

By the beginning of the twentieth century, a kind of division can be noticed within the directions of Arab nationalism. The differences can be encountered in the terms that were used in the newspapers and magazines at that period by the Arab intellectuals. There were two distinct words: Qawmiyya that is derived from Qawm and Wataniyya that is derived from Watan which can be translated into English as "Qawmiyya: Nationalism" and "Wataniyya: loyalty for the fatherland". The first term, Qawmiyya, was used to refer to pan-Arab nationalism. That is, it aimed at opposing the Ottoman Turks. The latter, by contrast, the Wataniyya was used to refer to patriotism, that is, it tried to make reforms inside the Ottoman Empire [Sela, Avraham. "Arab Nationalism." The Continuum Political Encyclopedia of the Middle East. Ed. Sela. New York: Continuum, 2002. p. 153]. Nonetheless, due to the foreign influences as well as the Ottoman defeats in the wars in the Middle East and in the Balkans, the Qawmiyya became more common among most of Arab intellectuals and the Arab tribes.

Some of Arabs, especially Iraqi Arabs, worked on a path that tried to oppose any attempt that aimed at reducing the Sultan's power. Those Arabs had the sense of nostalgia to the fatherland, Watan. Nevertheless, a large number of Arab intellectuals were in harmony that the term Arabism, Qawmiyya, is the correct one since Young Turks tried to Turkify the whole Ottoman Empire. These Arabs, by the word Arabism, tried to oppose the Ottomans, and especially the Young Turks [Weldon C. Matthews. Confronting an empire, constructing a nation: Arab nationalists and popular politics in mandate Palestine. I.B.Tauris. 2006. p. 14]. This part of Arabs was lead by the two sons of Sharif Hussein, Abdullah and Feisal. Meanwhile, it is unfair to generalize what Feisal Bin Sharif Hussein did against the Ottomans to the whole Arabs, and especially those of Iraq, since Feisal was not originally Iraqi and not supported by the Iraqis.

Arab nationalism of outside Iraq, in deed, was different from the one of inside Iraq. Arabs outside Iraq, especially those of Levant and Egypt were influenced by the British propaganda that a Caliphate of Arabia would be established for the
Arabs. Such promises that aimed at splitting Arabs from the Ottoman Empire were given by the British mandate, McMahon, in Egypt to Sharif Husain's son, Abdullah [Timothy J. Paris. Britain, the Hashemites, and Arab Rule, 1920-1925: the Sherifian solution. Routledge. 2003. pp. 322-3]. Moreover, when Hashemites started their revolt against the Ottomans in the Arabia, the Hashemites could have direct contact with British through T.E Lawrence [Mary Wilson. "The Hashemites, the Arab Revolt, and Arab Nationalism" in Rashid Khalidi, et al. (eds), The Origins of Arab Nationalism. (New York, 1991), p. 213]. The Hashemites got moral and logistic supports from Britain so as to expulse the Ottomans in the Arabia. Nevertheless, When the British Empire repented in her promises and committed herself to the Sykes-Picot treaty, all the Arabs severely opposed Britain.

Several messages were exchanged between the British mandate in Egypt and Sharif Husain. Abdullah bin Husain became a messenger between his father and McMahon. Although some of the intellectual Arabs were happy of the British promises, most of Sharif Husain's decisions were made unilaterally. Iraqi people, on the other hand, had a sense of loyalty to the Ottoman Sultan as well as the "Fatherland"[ Michael Curtis. The Middle East reader. Transaction Publishers. 1986. p. 77]. It is obvious from historical resources that there was very little or even no communication between Iraqi Arabs and those who supported Sharif's sons. Iraqis were not optimistic of any alliance with the Western powers. As a result, Arab nationalism was divided into Arabism, anti-Ottomans, and patriotism, Ottomanism in the early Twentieth century.

\section{Iraqi Peoples' Opposition to the European Companies}

Feisal and his brother, Abdullah, had no relation with the Arab nationalists in Iraq until the British mandate established the Kingdom of Iraq and appointed Feisal as its king in the Cairo Conference in March 1921. Although very few Sunni Iraqi Arabs due to their travels to the Levant met with Abdullah and Feisal. In that period, Iraqi people opposed the existence of British companies and the Western monopoly in the three Ottoman provinces, Basra, Baghdad, and Mosul. Indeed, until the Cairo Conference no state like Iraq existed. What was mentioned in the Ottoman and British documents were only these three provinces in which they were equal to the other Ottoman provinces. Thus, Arabs in Iraq differed from Sharif Hussein's sons in which the two sons were against the Ottomans while Iraqi Arabs were against the West rather than the Ottomans.

The Arab nationalism in Iraq during the last years of the Ottoman rule can be measured as Islamism, Ottomanism, anti-Europeanism, and to some extend anti-Young Turks. These ideologies can be noticed through the events that happened in Mesopotamia during the rule of the Young Turks. Apart from the Shiite claims on autonomy of the Basra province and some districts of the Baghdad province in the early twentieth century, Iraqi Arabs including Christians, Jews, Sunnis and Shiites were not welcomed with the CUP decisions ["Iraq-The Ottoman Period, 15341918", retrieved on "21 April 2012", available at: 


\section{International Journal of Science and Research (IJSR) \\ ISSN (Online): 2319-7064 \\ Index Copernicus Value (2013): 6.14 | Impact Factor (2014): 5.611}

http://www.mongabay.com/history/iraq/iraq-

the_ottoman_period, 1534-1918.html.]. Nonetheless, the Iraqi opposition was not against the Ottoman Sultan; however, it was against the Young Turks Turkification on the pan-Islamic countries. Because of their Islamic attitudes Iraqi people backed the Ottoman Sultan and revolted against the Young Turks, in words and deeds [I bid].

In order to prove the existence of anti-Europeanism, Ottomanism, and anti-Young Turkism inside the Iraqi Arab nationalism during the Young Turks rule, this chapter will conduct a research on two official plans of the CUP, one in 1909 and the other in 1913. In his article, "Iraq Before World War I: A Case of Anti-European Arab Ottomanism" [Mahmud Hadad. "Iraq Before World War I: A Case of Anti-European Arab Ottomanism" in Rashid Khalidi, et al. (eds), The Origins of Arab Nationalism. (New York, 1991), p. 120], Mahmud Haddad focuses on two major cases proving the Arab opposition towards the existence of any foreign (non-Muslims coming from abroad) company and power in the region. Both of these two cases explain how Shiite and Sunni Arabs, Christians, and Jews, in all the types of Iraqis including the deputies of Baghdad and Basra provinces, oppose any contract between the Ottomans and the West.

The first Iraqi people's opposition to the European companies belongs to 1909, when the Ottoman government was going to sign a contract with the British company. This was to merge the "Ottoman streamer line, the Nahriyya, with the British Messrs. Lynch Brothers Company"[ Rashid Khalidi. The Origins of Arab Nationalism. p. 121]. According to this contract, the Ottoman streamer line, the Nahriyya and the British Messrs Lynch Brothers Company join and make a bigger organization for thirty five years in which the Nahriyya becomes a part of the Messrs. Lynch. Moreover, the Messrs. Lynch has a particular right of complete control over the rivers Tigris and Euphrates. The contract could be prolonged by the Ottoman Empire after two years of the mean time, that is, after thirty-seven years [Tawfiq Barru. Al-Arab wal-Turk fil-ahd al-dusturi al uthmani, 1908-1914 (The Arabs and Turks during the Ottoman constitutional era, 1908-1914). Cairo: 1960. p. 129].

From the very beginning, the project was rejected by all the continents of the Iraqi people. This attempt was protested by the Lower Chamber of Deputies of the Ottoman parliament "Majlis al-Mab'uthan". Within a glance on the telegrams sent to Istanbul in December 1909, it is obvious that the Arabs, Christians, Jews and deputies of Basra and Baghdad did not use any offensive word against the Ottomans, though showed their criticism to the cabinet's decision. In the telegram, they raised the dire consequences of the amalgamation, including the outcomes that would negatively affect the Ottoman Empire. Therefore, it must be said that this protest which was sent through a telegraph to Istanbul was not against the Ottomans; by contrast it was against the Western monopoly over the streamer line.

The Iraqi telegram to Istanbul focused on several disadvantages for the Iraqi people as well as the Ottoman Empire. According to the contents of the project the price of travel could have been increased by the British company. The local merchants of Baghdad claimed that they would pay the same amount of money and commit to more conditions of the government [Consul-General Lorimer Memorandum respecting "Affaire Lynch in Irak (December and January 1910)." Foreign Office Archives, Public Record Office, London, FO 424/222. pp. 101-6]. For the Ottoman Empire, on the other hand, the disadvantages would be more serious. It will be more difficult for the government in case of army transport. Furthermore, the project might have political consequences on the rebellious tribes [I bid]. As a result, the project was not in favor of Iraqi tribes, merchants and also other constituents of the Iraqi people. Also, the project would create problems to the Ottoman Empire. Therefore, the opposition, here, is not against the Ottoman Empire, but was against the Young Turks' decision as well as the Western monopoly.

In December 1909, many meetings were held about the amalgamation project and several telegrams were exchanged between Baghdad, Basra, Mosul and Istanbul. The Baghdad, Basra, Mosul and Dayr-al-Zur's representatives insisted on abolishing the amalgamation and tried to convince the Ottoman cabinet not to ratify the agreement. The authorities in Istanbul, by contrast, tended to sign the agreement despite all the clarifications and disadvantages of the amalgamation told by the three Iraqi provinces' representatives. In the Iraqi side's telegrams a kind of begging as well as empathetic manner can be noticed while the ones coming from Istanbul was in case of urging rather than persuading the protestors.

In 15 December 1909, the Baghdad branch of CUP approved a resolution about the amalgamation concession appointing a delegation of Abdul-Jabbar Khaiyatzadah, Manahim Salih, Yahuda Zaluf, Wafik Bey, and Yusuf Shantub to meet with the Vali and complain against the navigation exempt "in the name of the mercantile community and other inhabitants of Baghdad" [Rashid Khalidi. The Origins of Arab Nationalism. p. 122]. In return, the Chamber of Deputies in Istanbul replied them and insisting the majority of the members of the Chamber voted for the navigation concession. So, this reply pressured the Iraqis to make more efforts to fail the project; therefore, they held more meetings and sent more telegrams.

The mercantile community tried to oppose the Turkish cabinet's attempts in two different ways. First, they tried to convince the authorities in Istanbul by showing sympathy to them. Secondly, they encouraged ordinary people of Iraq, especially tribes, to aggressively oppose the concession through demonstration using offensive words. The main reason behind this was that if they were alone then their arguments become less powerful. Moreover, if the merchants opposed the project violently then they might have been banned from trade or the government might have punished them.

By then, the anti-amalgamation people in Iraq sent more telegrams, but this time not only to Istanbul, it was to all the deputies of Arab provinces as well as the editors of some newspapers in Istanbul. This was because in the December $19^{\text {th }}$ telegram sent from Istanbul, Iraqis were indirectly informed that the ratification is not related to the Iraqi 


\section{International Journal of Science and Research (IJSR) \\ ISSN (Online): 2319-7064 \\ Index Copernicus Value (2013): 6.14 | Impact Factor (2014): 5.611}

acceptance or refusal; it was fully related to the votes of the members of the CUP members. Therefore, on 20 December, a telegram was sent to all the deputies of Arab provinces as well as important figures of the Ottoman government [Rashid Khalidi. The Origins of Arab Nationalism. pp. 1223]. In that telegram, they argued that this navigation concession would very negatively affect the life of Iraqi people since their life was to a great extend dependent on the Tigris and Euphrates rivers.

In 21 December 1909, the Mosul, Basra, Baghdad branches of CUP and the Vali of Baghdad sent telegrams individually to Istanbul [I bid]. In the Basra telegram a strong opposition to the project was showed. In the Vali of Baghdad's telegram a more sympathetic protest against the concession to the foreigners could be noticed. The Vali asserted that the people of Baghdad were not against the government's decisions. He argued that the problem was that the Baghdad inhabitants and merchants were against the foreigners. That is, if the government must sell them, then the local merchants would buy them and this would be accepted by all other provinces of Basra, Mosul, and Dair az-Zur [ConsulGeneral Lorimer Memorandum respecting "Affaire Lynch in Irak (December and January 1910).” pp. 101-4].

In light of the mentioned events and telegrams, it is obvious that these oppositions were not ideologies but were matters of interest. Although the Arab merchants in all the religions and other inhabitants of Iraq protested against the amalgamation project, their opposition was stemmed out from the fear of the loss of their interests [Batatu, Hanna. The Old Social Classes and the Revolutionary Movement of Iraq. Princeton University Press. 1978. p. 293]. Each merchant knew that if the project was ratified then this would very badly affect their trade due to the increase of tax. Nonetheless, due to all these efforts to fail the navigation concession, the project of merging the Nahriyya with the British Messrs. Lynch Brothers Company was not ratified and thus failed.

All in all, in the oppositions against the amalgamation, the merchants and other inhabitants of Iraq did not intend to oppose the Sultan; on the contrary, the position of the Sultan became more powerful. Nonetheless, a kind of opposition between the Turkish and the Arab members of the CUP, (Committee of Union and Progress), was encountered. The Turkish members backed the project of amalgamation due to the fact that the project did not include the Turkish regions. Meanwhile, the Arabs opposed the project for this would have negative financial effects for them, since the Euphrates and the Tigris located in the Arab lands and thus the British Company could raise their taxes.

\section{Iraqi Arabs' revolts against the West}

\subsection{Iraqi peoples' opposition against the Western monopolization:}

Arab nationalism as an index of opposition against the British monopoly and Young Turks' new policies can be noticed very obviously in the developments of 1913. In that year, a very clear split can be noticed between the Turkish authorities in Istanbul and Arabs of Iraq. Nonetheless, the
Iraqi protests were not against the Sultan. Indeed, the Iraqi people praised the Ottoman Sultan. The real opposition was between the Young Turks' government and the Western monopoly in the region.

From 1911 to 1913, the Ottoman Empire was in very destructive and huge wars in Tripoli and Balkans. These two wars brought the Ottomans to be bankruptcy. Therefore, the government tried to solve the financial crisis by selling the Saniyya, or Crown lands, owned by Sultan Abdulhamid that included lands in the provinces of Baghdad, Basra, Aleppo, and Beirut [Walid Khadduri. Social Background of Modern Iraqi Politics. (Pd.D. Thesis) Johns Hopkins University. 1970. p. 249]["Al-aradi al-amiriyya". Al-Mufid, July 7, 1913. p. 2]. These lands were, later on, renamed to be Mudawwara lands so that it can be sold. This decision was followed by very large protests and oppositions in the Arab world, especially in Iraqi two provinces Baghdad and Basra. Therefore, Arabs criticized the CUP but not the Sultan.

As mentioned before, Arab deputies and merchants, showed their opposition within a sense of loyalty for the government and the Ottoman Sultan in their protest against the amalgamation concession. In this phase, by contrast, an obvious opposition from the Shiite and Sunni Arabs from Baghdad and Basra against the CUP can be felt. The Arabs thought that the Ottoman cabinet sells them to the foreigners. The main reason behind the change of this protest from the other one in 1909 is that this time Crown lands in Palestine and Syria were included. Therefore, the Arabic newspapers in Levant paid more attention to this decision and offensively opposed the concession.

People in Basra province made a vast meeting on 18 July 1913. In that meeting which was headed by Sayyid Talip alNaqib decided to make all their efforts to oppose the project. It was said that the lands would be sold to Jew. Moreover, their empathy to their lands as well as lands of Palestine angered them. Sayyid Talip ordered to shut all the shops of Basra and they telegraphed to Istanbul that the Turkish officials must leave their province excluding the Vali, the commandant and one of the judges [Rashid Khalidi. The Origins of Arab Nationalism. p. 131]. Therefore, tensions occurred between people in Basra and authorities in Istanbul.

The seriousness of the case appears within the events of that time. The tensions in Basra led to the resignation of the Vali. These tensions and developments of Basra were coincided with the same events in Baghdad and Mosul. In Baghdad, a mass meeting was conducted on the future of Baghdad province since half of the province was measured as the Saniyya lands [Walid Khadduri. Social Background of Modern Iraqi Politics. p. 218]. The meeting which was held by a variety of all the constituents of Baghdad's inhabitants elected Abd al-Qadir al-Khudayri as president. Further, they "decided to arrange a large demonstration to protest the sale of these lands" [I bid]. People in Iraq informed the Vali so as to permit them to organize the demonstration. The Vali permitted them and also informed the Ministry of Interior of the danger of the situation. 


\section{International Journal of Science and Research (IJSR) \\ ISSN (Online): 2319-7064 \\ Index Copernicus Value (2013): 6.14 | Impact Factor (2014): 5.611}

On 29 July 1913, the British-Ottoman convention was signed. According to the contents of that agreement a clear monopoly right in the Mesopotamian Rivers was given to the British side by the Ottoman Empire [G. P. Gooch and Harold Temperley. Eds., British Documents on the Origins of War, 1898-1914. (London: His Majesty's stationary Office, 1939). 10:2. 183-94]. Against this agreement and the Mudawwara lands, Sayyid Talip and some of Basra's people established the Basra Reform Committee (or Basra Reform Society) so as to prevent the government's intention [Charles Tripp. A History of Iraq. Cambridge University Press: Cambridge. 2002. p 24]. The committee, by then, changed its strategy completely. They claimed for the right of autonomy so as to prevent any attempt of monopolizing Basra. By this, they tried to be far away from the threats of Istanbul as well as the ones of Britain.

Before declaring their claim of autonomy, people in Basra opposed to the Young Turks' centralization. Furthermore, one of the evidences, which proves Iraqi Arab sense of loyalty to the Sultan as well as their opposition to the Turks, is that "Sayyid Talib described the CUP Turkish members as atheists who deprived the Islamic caliphate of its power"[ Rashid Khalidi. The Origins of Arab Nationalism. p. 136]. Hence, Sayyid Talib in the protests against the amalgamation was seen as a leader of Arab nationalism and remained as so even during the British rule. Therefore, Arab nationalism during last years of the Ottoman rule can be measured as anti-Europeanism, anti-CUP, Ottomanism, Islamism and then Arabism since people in Basra concentrated on the terms that are related to Islam.

It is taken for granted that no protest or opposition from the Iraqi nationalists can be seen against the Ottomans until the Young Turks started to centralize the Ottoman Empire. Furthermore, the Turkification of education system and administrative works split Arabs from the Ottoman Empire. In her work on the history of Iraq, Helen Chapin Metz argues that the Young Turks' Turkification pushed the Iraqi nationalists to meet "in Cairo with the Ottoman Decentralization Party"[ Leon M. Jeffries. Iraq: issues, historical background, bibliography. Nova Publishers. 2003. p. 140]. In addition, some of Iraqi nationalists "joined the Young Arab Society, which was moved to Beirut in 1913" [I bid]. Despite all these opposition, no Iraqi Arab nationalist protested or opposed against the Ottoman Sultan. The Iraqi Arab nationalism at that time was, in deed, against the Western monopolization that is why they opposed the Ottoman governments' projects that were bringing the West to the region.

\subsection{Iraqi Arabs' revolts against the UK}

In the early twentieth century, Britain was looking for a gateway to get in touch with its forces in India and the oil reserves in the Middle East. When the Ottomans sided the Central Powers, the British thought that they were surrendered. Britain started to fight the Central Powers everywhere. Since the Persian Gulf was rich of oil, the Britain tried to expand its interests there. For the first time, the British forces landed in Fao on 6 November 1914 and within that year they could reach Basra Province [Peter Sluglett. Britain in Iraq: Contriving King and Country.
I.B.Tauris. 2007. P. 9]. They were faced with intensive resistance from the Ottomans in their first attempt although they could enter the centre of Basra.

The British forces tended to occupy all three provinces of Mesopotamia. These forces remained in the same status quo until 1916. However, they fought with some tribes and Islamic motivated groups every now there. In October 1915, the British troops tried to occupy Kut and Al Amara, too [Peter Sluglett. Britain in Iraq: Contriving King and Country. I.B.Tauris. 2007. Pp 10, 11]. The Ottoman Empire enhanced its forces there so as that they could fall the British. Moreover, the Ottomans could get support from the religious attitude of the Arab people their and the tribes located in the region. Therefore, the British were extremely defeated in the attempts of 1915 and 1916 [I bid].

Despite the fact that British forces were tremendously destroyed in the battles of Kut and Northern Basra, they could succeed in their missions of occupying the whole Iraq. After several attempts of invading Kut and moving upward, the British Army could take control over the Kut in 3 June 1915. The city was retaken by the Ottomans in the same year but then finally on 25 February 1917 both of Kut and Al Amara were retaken by the British. Therefore, when they could win in the Al Amara Kut, their way to Baghdad became easier because the Ottomans were attacked every where, from Istanbul to the Levant and the Persian Gulf. Thus, on 11 March 1917, Baghdad was fallen to the Britain [http://www.historyworld.net/wrldhis/PlainTextHistories.asp ?HistoryID $=$ aa01\&paragraphid $=$ qel Retrieved on 28 April 2014].

Although the British army could reach all three Ottoman provinces, there were some regions that remained unoccupied in that period. The Kurdish highlands and the religious cities of Iraq could reign themselves independently for some years. Najaf and Karbala that are two religious and sacred cities for the Shiites could rule without any indulge from the British after 1916. The main reason behind this was the existence of many Shiite clerics as well as most of Arab nationalists there. Despite the religious classes, students in Najaf and Karbala were supposed to study the history of Arab civilization [Reeva S. Simon, Eleanor Harvey Tejirian. The Creation of Iraq, 1914-1921: The View from Baghdad. Columbia University Press, 2004. p. 21].

When Britain came to the Persian Gulf in 1914 and occupied the some parts of Iraq in 1915, a change occurred in the Iraqi Arab nationalism. At the beginning, almost all the Arabs of Iraq, including Sunnis and Shiites, backed the Islamic caliphate, the Ottoman Empire. Ayatollah Muhammad Taqi al-Shirazi other Shiite clerics of Najaf and Karbala issued a Fatwa and called for Jihad against the British forces everywhere in the region. In addition, they argued that any relation and service in the British Administration was prohibited [Abd al-Razzaq al- Hasani. Al-Thawra alIraqiyya al-Kubra. Sidon. 1952. p. 34]. At that time, the Sunni officers, who were trained in Istanbul, were divided. A part of them backed the Shiites and revolted against the British. The other part, on the other hand, waited to see who would be the winner. Sunni Arab Nationalists, like Abdurrahman Al-Naqib, created a good relation with the British civil administration in Baghdad [I bid]. 


\section{International Journal of Science and Research (IJSR) \\ ISSN (Online): 2319-7064}

Index Copernicus Value (2013): 6.14 | Impact Factor (2014): 5.611

In the end of the occupation campaign of Iraq, the British gave the people different and great promises. They promised Kurds in the North with an independent Kurdistan. Meanwhile they promised Arabs with a Caliphate of Arabia. Because British Army was a non-Muslim army, it was not welcomed by the majority of the Shiites and some of Sunni Arabs. Furthermore, Britain tried to split all the Iraqi people from each other so that they would not gather themselves and oppose British zone of influence. The tribal Sheikhs got more benefit from the British and that is why they liked the continuation of the British rule. Further, The British companies provided tribal Sheikhs with developed guns. Therefore, well-armed tribes existed in the region by which some of them, especially the Sunni ones, fought one another [Reeva S. Simon, Eleanor Harvey Tejirian. The Creation of Iraq, 1914-1921: The View from Baghdad. Columbia University Press, 2004. pp. 38-40].

Despite the fact that the Iraqi Arab opposition against the British occupation was very strong in Najaf, Karbala and Baghdad, there were some Arabs who took their personal interests as more important than everything. Some tribal Sheikhs asked the British Administration to continue on the Ottoman privileges in their districts. Furthermore, some of the Arab intellectuals thought that Britain would fulfill its promises and an independent state would be established for the Arabs in the Middle East. Nonetheless, the Arab silence towards the continuation of British occupation of Iraq did not last more than one year and mass demonstrations and revolutions occured.

Most of the Arabs of Baghdad and Basra whether Shiites or Sunnis, started to revolt the occupation and asked for the fulfillment of previous British promises in 1920. The Shiites, in Najaf and Karbala, and Sunnis, in Baghdad and Anbar, used such religious ceremonies as ta'ziyya, $10^{\text {th }}$ of Muharram, Mawlud and Ramadan to provoke people to revolt the British Army [I bid]. Several battles happened between Iraqis and Britain that cost Iraqi their lives and money and cost Britain a very huge amount of money. Although Iraqi people could not free their country from the British Mandate, they could give a lesson to Britain that they were not welcomed since they came by force. Therefore, Arab nationalism in Iraq, in that period, is in another version of anti-Foreignerism or anti-Europeanism as well as Islamism.

\section{Conclusion}

Nationalism entails a strong recognition of a group of people's social identity with that of a nation or state and an ethnic identity with a state. Nationalism is mainly related to linguistic, cultural, religious, and historical heritages of a common people. One of the main purposes of nationalism is to have a collective identity, that is a nation or a group of people must have one single national culture. Therefore, the term Nationalism has been used a means to succeed states and nations. In this context, French nationalists were the first people who tried to take advantage from nationalism so as to enlarge their borders in the late eighteenth century.

After the Ottoman defeats in the Balkans and the Western nationalists' triumphs in the nineteenth century, a voice of opposition was raised in the Ottoman Empire. A group of Young Turks favored of the Ottoman system against the monarchy of the Ottoman Sultan. The Young Turks were a group of Turkish intellectuals who used a Turkification policy within the whole Ottoman Empire. This policy was strongly opposed by all the Ottoman peoples especially by the intellectual Arabs. Some of these intellectuals were motivated by Christian missionaries in Levant as well Egypt. Therefore, a kind of opposition within the sense of Arab nationalism appeared in the Arab literature.

The Arab nationalism that occurred in the late nineteenth century was divided into two types. The first kind of Arab nationalism can be explained within the term Qawmiyya, which was used to refer to pan-Arab nationalism. That is, it aimed at opposing the Western powers as well as the Ottoman Turks. The Qawmiyya was common in Levant and Egypt. The second sort, by contrast, was Wataniyya, which was used to refer to patriotism. According to this type of Arab nationalism, nationalists should have a sense of loyalty to the fatherland, that is, they tried to make reforms inside the Ottoman Empire. The Wataniyya sense was supported by Arab nationalists in Iraq.

The Arab nationalism inside Iraq was quite different from the one of outside Iraq. The Arab nationalism in Levant and Egypt can be identified as anti-Ottomanism as well as antiEuropeanism. These interpretations could be clearly seen within the Arab revolts against the Ottomans in the early twentieth century. The Iraqi Arab nationalism, on the other hand, can be regarded as Ottomanism, anti-Europeanism, Islamism, as well as anti-Young Turks. In this paper, many clues are given so as to prove how Iraqi people praised the Ottoman Sultan and opposed the European existence in the region. The main reason behind this praise might be related to the Iraqi people's empathy to Islam and according to Islamic law there must be a unitary state for the whole Muslims under the Caliphate rule.

The Iraqi Arabs opposed any agreement and project that legalized the presence of non-Muslim powers in the Mesopotamia. In 1909, the Ottoman cabinet was to sign the project of the amalgamation of the Ottoman streamer line, the Nahriyya, with the British Messrs. Lynch Brothers Company. This was aggressively opposed by all the constituents of Iraqi people. According to the telegrams sent from Baghdad, Basra and Mosul to Istanbul, the Iraqi merchants and other ordinary Iraqi inhabitants did not mind the amalgamation of the Nahriyya to other companies. Instead, they argued that they are not welcomed with any foreign companies. They claimed that their only purpose was to oppose the Western monopoly of the Muslim waters. Therefore, in the refusal of the navigation concession the Arab nationalism in Iraq could be interpreted as Islamism, Ottomanism, anti-Europeanism as well as anti-Young Turks.

The Iraqi Arab nationalism became stronger when the Ottoman government tried to sell the Saniyya lands in 1913. These lands were belonging to Sultan Abdulhamid. Iraqi Arabs very aggressively responded to this idea. In Baghdad mass meetings that were attended by hundreds of inhabitants of Baghdad started. They sent several telegraphs to Istanbul showing their complete refusal to the sell of those lands. In 


\section{International Journal of Science and Research (IJSR) \\ ISSN (Online): 2319-7064 \\ Index Copernicus Value (2013): 6.14 | Impact Factor (2014): 5.611}

Basra, in addition to the demonstrations and making telegraphs to Istanbul, Arab nationalists established the Basra Reform Community claiming for autonomy. Although they opposed the Ottoman government's decision, they still praised the Ottoman Sultan. As a result, a kind of Islamism, anti-Westernism and anti-Ottoman government could be noticed within the sense of Arab nationalism in Iraq.

The Iraqi Arab nationalism was clearly occurred when the British occupied Iraq in 1916 and upwards. By the coming of the British forces to Iraq, most of the Ottoman laws have been changed and this was very strange for the Iraqis. The Arab nationalists made demonstrations in almost all the Iraqi cities. Nonetheless, The British could successfully separate city dwellers from tribes inhabited to the villages by giving money and guns to the tribes. Between 1918 and 1920, the Iraqi Arab nationalists started to form militant groups and movements to free their lands from the foreign powers. Thus, the whole Iraqi Arab nationalism can be summarized mainly into anti-Europeanism, Islamism as well as Ottomanism.

\section{References}

[1] Abd al-Razzaq al- Hasani. Al-Thawra al-Iraqiyya alKubra. Sidon. 1952.

[2] Batatu, Hanna. The Old Social Classes and the Revolutionary Movement of Iraq. Princeton University Press. 1978.

[3] Charles Tripp. A History of Iraq. Cambridge University Press: Cambridge. 2002.

[4] Consul-General Lorimer Memorandum respecting "Affaire Lynch in Irak (December and January 1910)." Foreign Office Archives, Public Record Office, London, FO 424/222.

[5] Eric Hobsbawm. The Age of Revolution, 1789-1848. New York: New American Library.1962.

[6] Ernest Dawn. "The Origions of Arab Nationalism" in Rashid Khalidi, et al. (eds), The Origins of Arab Nationalism. (New York, 1991).

[7] Ernest Gellner. Nations and nationalism, Bölüm 1-2; Bölüm 4-9. Wiley-Blackwell. 2006.

[8] Fatma Müge Göçek. Social constructions of nationalism in the Middle East. SUNY Press. 2002.

[9] G. P. Gooch and Harold Temperley. Eds., British Documents on the Origins of War, 1898-1914. (London: His Majesty's stationary Office, 1939). 10:2.

[10] Halim Barakat. The Arab world: society, culture, and state. University of California Press. 1993.

[11]Hiro, Dilip. "Arab nationalism." Dictionary of the Middle East. St. Martin's Press. 1996.

[12] Hutchinson, John and Smith, Anthony D. Nationalism. Oxford Readers. Oxford University Press: Oxford. 1994.

[13] John L. Esposito. The Oxford dictionary of Islam. Oxford University Press: US. 2004.

[14] Joseph Scott. The Black revolts: racial stratification in the U.S.A. : the politics of estate, caste, and class in the American society. Transaction Publishers. 1976.

[15]Leon M. Jeffries. Iraq: issues, historical background, bibliography. Nova Publishers. 2003.
[16] Mary Wilson. "The Hashemites, the Arab Revolt, and Arab Nationalism" in Rashid Khalidi, et al. (eds), The Origins of Arab Nationalism. (New York, 1991).

[17] Michael Curtis. The Middle East reader. Transaction Publishers. 1986.

[18] Reeva S. Simon, Eleanor Harvey Tejirian. The Creation of Iraq, 1914-1921: The View from Basra. Columbia University Press, 2004.

[19] Samir Kassir. Being Arab. Verso. 2006.

[20] Sela, Avraham. "Arab Nationalism." The Continuum Political Encyclopedia of the Middle East. Ed. Sela. New York: Continuum, 2002.

[21] Sluglett, Peter. Britain in Iraq: Contriving King and Country. I.B.Tauris. 2007.

[22] Smith D. Anthony. Nationalism: theory, ideology, history. Wiley-Blackwell. 2001.

[23] Tawfiq Barru. Al-Arab wal-Turk fil-ahd al-dusturi al uthmani, 1908-1914 (The Arabs and Turks during the Ottoman constitutional era, 1908-1914). Cairo: 1960.

[24] Timothy J. Paris. Britain, the Hashemites, and Arab Rule, 1920-1925: the Sherifian solution. Routledge. 2003.

[25] Thomas Blank and Peter Schmidt, National Identity in a United Germany: Nationalism or Patriotism? An Empirical Test with Representative Data, in Political Psychology, Vol. 24, No. 2. 2003.

[26] Weldon C. Matthews. Confronting an empire, constructing a nation: Arab nationalists and popular politics in mandate Palestine. I.B.Tauris. 2006.

[27] Walid Khadduri. Social Background of Modern Iraqi Politics. (Pd.D. Thesis) Johns Hopkins University. 1970.

[28] http://www.historyworld.net/wrldhis/PlainTextHistories. asp? HistoryID=aa01 \& paragraphid=qel. Retrieved on 28 April 2014. 